\title{
Initial Pulp Changes During Orthodontic Movement: Histomorphological Evaluation
}

\author{
Milton SANTAMARIA Jr. ${ }^{1}$ \\ Débora MILAGRES ${ }^{2}$ \\ Mamie Mizusaki IYOMASA ${ }^{3}$ \\ Maria Bernadete Sasso STUANI ${ }^{4}$ \\ Antonio Carlos de Oliveira RUELLAS ${ }^{1}$
}

\author{
${ }^{1}$ Department of Orthodontics and Pediatric Dentistry, School of Dentistry, Federal University of Rio de Janeiro, RJ, Brazil \\ ${ }^{2}$ Institute of Biology, Federal University of Rio de Janeiro, RJ, Brazil \\ ${ }^{3}$ Department of Morphology, Stomatology and Physiology, School of Dentistry of Ribeirão Preto, \\ University of São Paulo, Ribeirão Preto, SP, Brazil \\ ${ }^{4}$ Department of Pediatric Clinic, Preventive and Social Dentistry, School of Dentistry of Ribeirão Preto, \\ University of São Paulo, Ribeirão Preto, SP, Brazil
}

\begin{abstract}
This study evaluated pulp changes in molars of rats submitted to tooth movement by application of a $0.4 \mathrm{~N}$ force. Twenty-five adult male Wistar rats (Rattus norvegicus, albinus) were randomly assigned to 5 groups $(n=5)$, being one control group not submitted to force application, and four study groups of 6, 12, 24 and $72 \mathrm{~h}$ of force application. The study groups received a 5-mm long nickel-titanium closed coil spring, placed from the right maxillary first molar to the maxillary incisors of each animal. The coil spring was used for mesial inclination of the first molar. After the specific period of tooth movement of each study group, the animals were sacrificed and specimens containing the teeth submitted to movement were processed and stained with hematoxylin and eosin for histological analysis under light microscopy. The results demonstrated alteration of the odontoblastic layer, with hypertrophy of odontoblasts especially at the mesial area of the coronal pulp, edema of the pulp connective tissue in the central area of the pulp, and vascular alteration with accumulation of erythrocytes and leukocytes inside the vessels, especially at the mesial root of the moved teeth. These changes were less remarkable for the 72-h period. Thus, it may be concluded that tooth movement yielded pulpal tissue alterations compatible with an inflammatory process, which are reversible if the aggression is not more intense than the physiological limit of tissue tolerance.
\end{abstract}

Key Words: pulp, tooth movement, histology.

\section{INTRODUCTION}

Pulpal microvasculature changes may be assigned to the application of orthodontic forces beyond the physiological limits of tolerance of the periodontal tissues and dentin-pulp complex (1), and may lead to an extreme reduction of the volume of the pulp cavity. Blood vessels that nourish the pulp may be damaged, with consequent hemorrhage, leading to tooth discoloration and possible pulp necrosis (2).

Butcher and Taylor (3) performed tooth movement in incisors of monkeys and observed pulp changes ranging from circulatory stasis to pulp necrosis.
Revascularization of this tissue occurred if the period of movement was extended. Another study (4) showed that intrusive forces applied to human premolars for 4 to 35 days might cause circulatory disturbances and vacuolization. The most remarkable histological alterations were found in teeth with completely formed roots. Anstendig and Kronman (5) conducted tooth movement in dogs and observed that the main pulp change was vacuolization and discontinuity of the odontoblastic layer of moved teeth. Also, it has been reported (6) that there is an initial pulp congested blood vessels in response to orthodontic movement. Their study was conducted in rats and comprised mesial 
inclination of the maxillary first molars.

A previous study of the pulp of premolars submitted to extrusion (7) verified the occurrence of edema, fibrosis, blood congestion and degeneration of the odontoblastic layer, which disagrees with the findings of Subay et al. (8), who did not report inflammatory reaction in study groups submitted to the same type of movement.

The aim of this study was to perform a qualitative evaluation of histological alterations of the pulp tissue in orthodontically moved teeth of rats.

\section{MATERIAL AND METHODS}

The study sample comprised 25 adult male Wistar rats (Rattus norvegicus, albinus) weighing approximately $300 \mathrm{~g}$, supplied by the Animal Laboratory of the School of Dentistry of Ribeirão Preto, University of São Paulo, Brazil. The animals received a standard diet comprising pelleted food (Labina; Purina Nutrimentos Ltda, São Paulo, SP, Brazil) and mineral water ad libitum. This procedure avoided easy damage to the appliance during feeding of the animals.

Each rat was anesthetized with an intraperitoneal injection of 2.5\% tribromoethanol (Aldrich Chemical Co., Inc., Milwaukee, WI, USA; 0.25 g/kg body weight). The experimental groups received a nickel-titanium closed coil spring (code 35.20.064, Morelli, Sorocaba, SP, Brazil) measuring $5 \mathrm{~mm}$ in length, placed from the right maxillary first molar to the maxillary incisors of the animal (Fig. 1). This coil spring was employed for

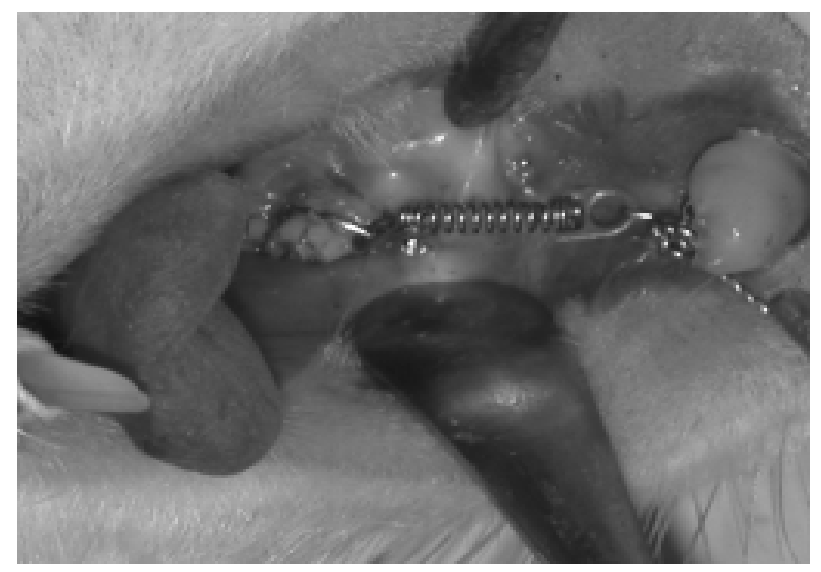

Figure 1. Intraoral photograph of appliance placed for tooth movement. mesial inclination of the first molar, by application of a $0.4 \mathrm{~N}$ force (9).

The animals were randomly assigned to 5 groups $(n=5)$, being one control group not submitted to force application, and four study groups of 6, 12, 24 and 72 $\mathrm{h}$ of force application.

After the study period, the animals were sacrificed by deep anesthesia with urethane $(1.5 \mathrm{~g} / \mathrm{kg}$ body weight intraperitoneally). Intracardiac perfusion was performed with saline (JP Indústria Farmacêutica, Ribeirão Preto, SP, Brazil) followed by $4 \%$ paraformaldehyde fixing solution dissolved in PBS, both in the amount of $7 \%$ of animal body weight. This procedure aimed at the achievement of a more effective and faster fixation of the tissues to be studied. Animals were decapitated and the maxilla was sectioned in the area of the right maxillary first molar. The pieces were processed, embedded in paraffin and serial longitudinal $6-\mu \mathrm{m}$-thick sections were cut in a mesiodistal direction, parallel to the long axis of the first molars. The sections were stained with hematoxylin and eosin (HE) and examined under light microscopy at X200 for analysis of the pulp structures and at X400 for a more detailed evaluation of cellular and vascular structures. Photomicrographs were obtained.

\section{RESULTS}

Histological examination under light microscopy revealed that teeth moved for the different periods presented changes in the pulp tissue structure, as demonstrated by cellular and structural events compatible with inflammatory process (Figs. 2 to 7 ).

In the control group, the odontoblasts were adjacent to the predentin layer, with the cell bodies at the periphery of the pulp and the cytoplasm extensions crossing the predentin layer and reaching the dentinal tubules (Fig. 2 A). In all study groups (6, 12, 24 and 72 h of tooth movement), the odontoblasts maintained their characteristic organization juxtaposed to the others, yet the nuclei had distended and diffused chromatin (hypertrophic, round-shaped) and the cytoplasm was more basophilic, with sparser cells when compared to the control group (Fig. 3). This alteration occurred mainly in the mesial surface of the pulp of the teeth submitted to movement.

In the 72-h group, the pulp displayed normal characteristics, but with changes in the odontoblastic layer at the mesial surface of the coronal pulp. The 
central area of the coronal pulp in the control group displayed the Weil zone, which is the cell-free zone at the periphery of the dental pulp (Fig. 2 B). The Weil zone in the study groups disappeared at the areas in which the odontoblastic layer was more altered and with larger cells. At 24 and $72 \mathrm{~h}$ of tooth movement, the odontoblasts exhibited again a normal aspect and the cell-free zone was once again normally observed on the coronal pulp.

A cell-rich zone was observed interiorly to this cell-free zone and was very clear on the pulp crown of the control group. This area was distinguished from the central portion of the pulp tissue because of the larger

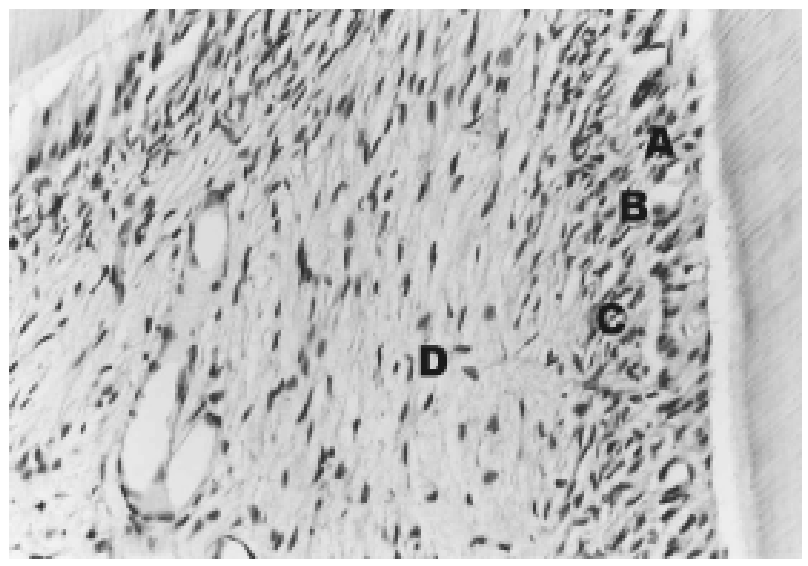

Figure 2. Photomicrograph of histological section of the dental pulp of the control group. $\mathrm{A}=$ odontoblastic layer; $\mathrm{B}=$ cell-free Weil zone; $\mathrm{C}=$ cell-rich zone; $\mathrm{D}=$ central pulp area (X200; HE).

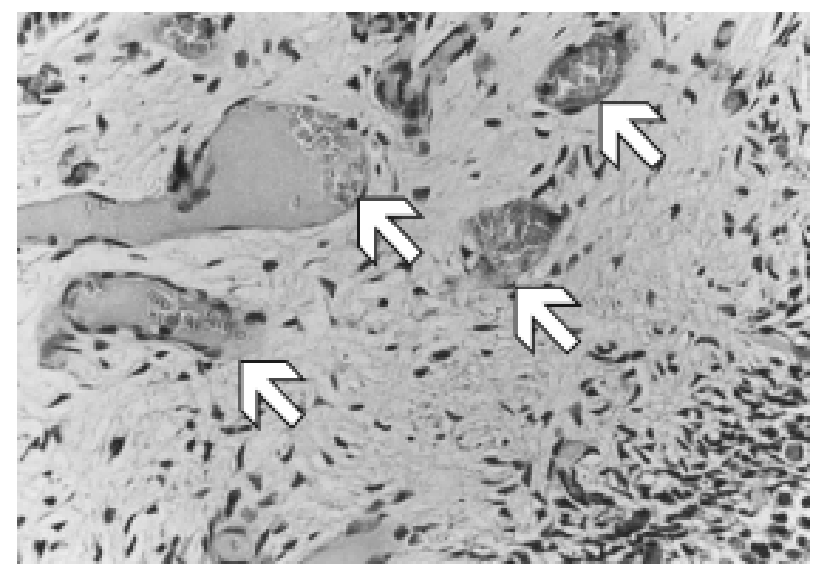

Figure 4. Photomicrograph of a histological section showing areas of congested vessels and edema in the pulp center of the 6h group (X400; HE). Arrows indicate areas of congested vessels. number of cells per unit of area, especially fibroblasts and undifferentiated mesenchymal cells (Fig. 2 C). The cell-rich layer was larger in all study groups compared to the control, with characteristic cells such as fibroblasts, undifferentiated mesenchymal cells and defense cells. This larger number of cells was especially observed in the mesial region of the coronal pulp.

Fibroblasts were the predominant cell type in the central area of the pulp in the control group. These cells displayed variable shapes with long and irregular cytoplasmic extensions, oval nucleus and lightly stained and homogeneous cytoplasm. Distribution of these cells in the pulp tissue was homogeneous, with a slight

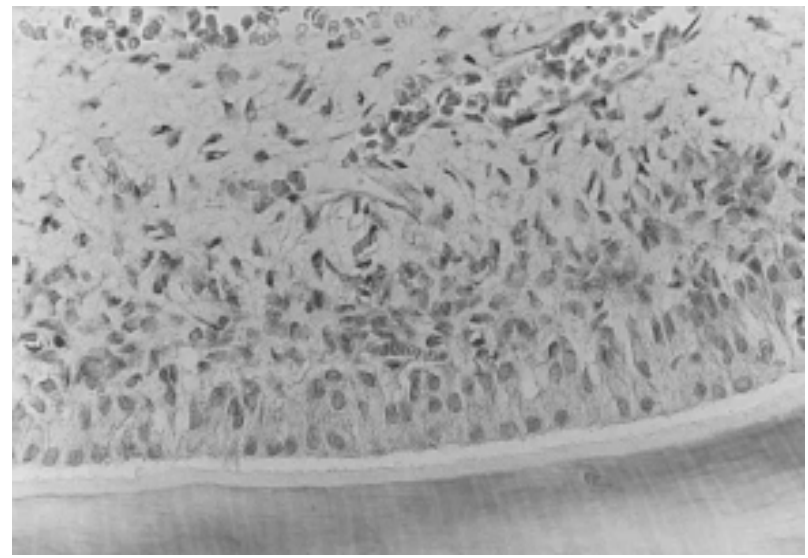

Figure 3. Photomicrograph of a histological section showing in detail the odontoblastic layer of the dental pulp of the 6-h group (X400; HE).



Figure 5. Photomicrograph showing the vascularization of the central layer of the pulp (control group; X400; HE). Arrows indicate vessels. 
increase around blood vessels. The intercellular substance of fibrilar nature was characterized by sparse collagen fibers throughout the pulp surface, with seldom formation of bundles at both the coronal and root pulp, on which they were thin and distributed in an undefined arrangement (Fig. 2 D). The fibers at the root pulp were parallel to the long axis of the tooth and slightly thicker than those at the coronal pulp. In the experimental groups, the nuclei of fibroblasts were more distant from each other due to the larger amount of extracellular matrix, suggesting accumulation of interstitial liquid and edema, rendering the tissue less homogeneous compared to the control group. The 6-h group exhibited areas of congested vessels in the central region of the pulp and especially at the root, characterized by the presence of erythrocytes (Fig. 4).

Vascularization in the control group was concentrated in the central region of the coronal and root pulp, characterized by the presence of wider vessels (Fig. 5). The capillaries were lined by a layer of squamous endothelial cells, being some with no contents and some containing blood cells. Vascularization in the study groups was also concentrated in the central zone of the coronal pulp and characterized by the presence of wider blood vessels, and in higher concentration close to the odontoblastic layer. The 6-h group displayed a higher number of blood cells, erythrocytes and also leukocytes inside the blood vessels. The number of erythrocytes inside the vessels was smaller in the other study groups, yet defense cells such as neutrophils, eosinophils and monocytes were observed in all study periods (Fig. 6). The vessels were still congested at 24 and $72 \mathrm{~h}$ and often displayed a substance with light purple staining, suggesting the presence of plasma proteins, especially on the mesial root.

The leukocytes observed in the blood vessels during tooth movement were also found inside the pulp connective tissue, in which eosinophils could be easily identified. Such cells usually have bilobed nucleus and cytoplasm with oval granules stained with eosin (eosinophilic granules).

Accessory root canals were also observed, especially at the furcation region of the molars in the control group and 72- h study group. These root canals contained blood vessels, nerves and collagen fibers and allowed contact between the pulp tissue and the connective tissue in the periodontal ligament (Fig. 7). At the initial periods of tooth movement $(6,12$ and $24 \mathrm{~h})$, the regions of accessory root canals presented signs of inflammatory reaction, yet to a milder extent compared to other regions. At the vicinity of accessory root canals there were fewer polymorphonuclear and mononuclear inflammatory cells and less congested blood vessels.

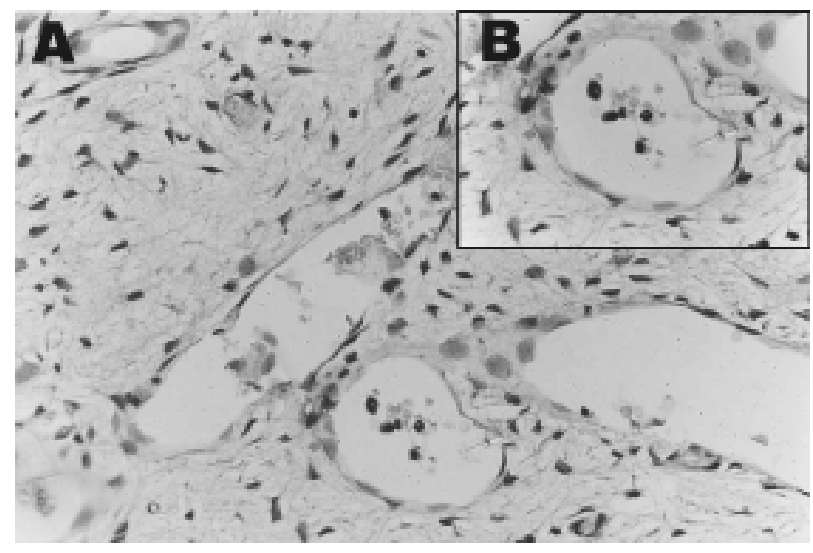

Figure 6. Photomicrograph showing blood cells inside the vessels. Erythrocytes and leukocytes. A) X400, HE; B) X1000, HE.

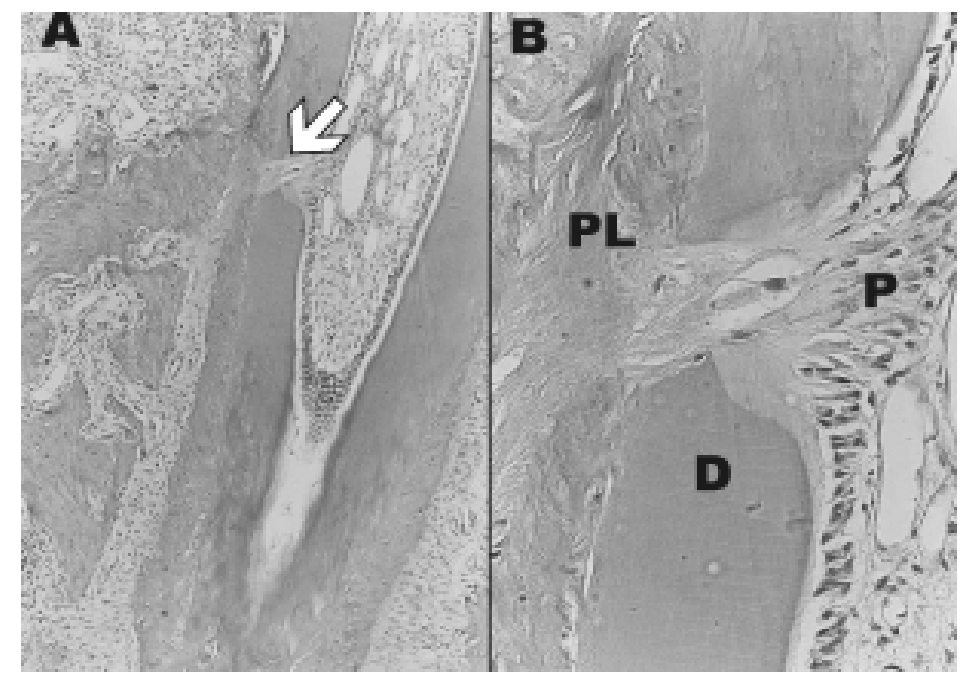

Figure 7. Photomicrograph of histological sections of accessory root canal of molars for the 72-h group. A) X200, HE - Arrow indicates an accessory root canal; B) X400, HE; PL = periodontal ligament; D = dentin; $\mathrm{P}$ = pulp. 


\section{DISCUSSION}

The initial response of the tooth pulp to aggression was not significantly different from that observed in other tissues, yet the final outcome may be remarkably different due to the stiffness of dentinal root canal walls. When an external stimulus reaches a noxious level there is degranulation of mast cells, biochemical reactions characteristic of inflammation and cell damage. Several mediators of inflammation (e.g. histamine, bradykinin, neurokine, neuropeptides, prostaglandins and growth factors) are released. These mediators generally induce vasodilatation, increase in blood flow and vascular permeability, and edema $(10,11)$.

In the normal tissue, the increased blood flow yields repair by removal of inflammation mediators, usually with a larger volume of the damaged tissue. However, the dental pulp is restricted to a limited area. The active dilatation of arterioles leads to an increase in pulp pressure and secondary compression of the venous return, which leads to restriction of arterial flow (10).

The present study showed significant vascular changes early in the first 6 hours of tooth movement, with congested blood vessels at this period. However, it is not possible to state whether there was decrease or increase in blood flow of the dental pulp because the specific methodology for assessment of this physiological alteration, such as utilization of laser doppler flow meter, was not employed $(12,13)$. Moreover, reports of such investigations are controversial, as histological studies in dogs have shown congestion of pulp blood flow (5). On the other hand, other investigations using laser doppler flow in vivo have revealed that the alteration in blood flow of the dental pulp is highly variable, depending on the type of movement, force applied and degree of root formation of the moved tooth (12).

The mechanical obstruction of the blood flow in tooth movement is related to the status of the pulp tissue, which is surrounded by inflexible walls and receives blood supply primarily from the apical foramen. Therefore, the presence of accessory root canals reaching the pulp tissue may influence the tissue reaction, allowing conditions for faster recovery of the pulp tissue when its blood circulation is altered due to compression of the apical foramen during tooth movement. Such recovery could be confirmed in tissues close to accessory root canals, even at the initial periods of tooth movement, when there was milder inflammatory infiltrate and less congestion of blood vessels (Fig. 7).

This study clearly demonstrated the presence of inflammatory cells throughout the study period, indicating an inflammatory process as a response to this aggression. Initial inflammatory cells could be observed inside the blood vessels and in the pulp connective tissue at 6 and $12 \mathrm{~h}$, as follows: neutrophils, which constitute the first line of cell defense against an aggression, being active phagocytes of small particles; eosinophils, which act as phagocytes, destruct certain antibody-antigen complexes and restrict the inflammatory process; and monocytes, which are also phagocytes and are kept in the blood for just some days, cross the walls of capillaries and venules, penetrate the connective tissue and are transformed into macrophages (14).

This reaction led to the appearance of macrophages originated from monocytes coming from blood flow and lymphocytes at 24 and $72 \mathrm{~h}$. Although morphologically similar, lymphocytes constitute a heterogeneous population of cells with different immunological characteristics. B-lymphocytes are involved in humoral defense by means of the synthesis of antibodies, whereas T-lymphocytes are involved in cell immune defense of the body and have as their main function the enhancement of antibody production by B-lymphocytes. These cells are thus called immunological memory cells (14).

Thus, the inflammatory process triggered by mediators released by these specific cells and the damaged tissue brought about significant changes in the layer of odontoblasts, more specific cells of the dental pulp (15). Their nuclei at 6 and $12 \mathrm{~h}$ were hypertrophic and followed the cell shape, probably demonstrating alterations in the metabolic activity of these cells (16, 17). The cell metabolism altered by the inflammatory process, with presence of edema and signs of vascular changes was clear in the early study periods and still observed at $72 \mathrm{~h}$; however, the odontoblasts in some areas then displayed normal aspect, demonstrating the excellent condition of pulp repair. If the aggression was more intense than the capacity of repair of this tissue and the study period was longer, there would probably be more severe cell degeneration, such as vacuolization of the odontoblastic layer, indicating cell death.

These alterations were histologically evaluated and do not allow establishment of the clinical symptomatology that the patient might present. The 0.4 $\mathrm{N}$ force applied was the same employed by Stuani (18) and this author observed predominance of direct bone 
resorption, indicating application of biologically compatible force. Nevertheless, the tissue alterations in the present study, with presence of inflammatory cells and congested vessels, were more frequently observed close to the mesial wall of the tooth, both in the root and coronal portions of the pulp. The findings in this area may be expected as the movement performed was mesial inclination of the molar, which tends to concentrate more forces in this area. Regarding pulp changes, it may be stated that the tissue reactions always occur during tooth movement and thus professionals should always apply biologically compatible forces.

This study did not find any sign of pulp necrosis, suggesting that the tissue changes indicate reversible pulpitis, in which the tissue is able to recover its normal healthy status in case the noxious stimuli are ceased. In conclusion, tooth movement yielded pulpal tissue alterations compatible with an inflammatory process, which are reversible if the aggression is not more intense than the physiological tissue tolerance limit.

\section{RESUMO}

Este estudo avaliou alterações pulpares em molares de ratos movimentados com amplitude de força de 0,4 N. Vinte e cinco ratos machos adultos Wistar (Rattus norvegicus, albinus) foram aleatoriamente alocados em 5 grupos $(n=5)$, sendo 1 grupo controle não submetido à aplicação de força, e 4 grupos teste submetidos a 6, 12, 24 e 72 h de aplicação de força. Os grupos teste receberam uma mola fechada tipo coil spring de níquel-titânio com $5 \mathrm{~mm}$ de comprimento, fixada do primeiro molar superior direito até os incisos superiores do animal. A mola tipo coil spring foi utilizada para mesialização do primeiro molar. Após o período específico de movimentação de cada grupo experimental, os animais foram sacrificados e as peças contendo o dente movimentado e o seu tecido pulpar foram processadas e coradas com hematoxilina e eosina para análise histológica em microscopia de luz. Os resultados mostraram alteração da camada de odontoblastos com hipertrofia dessas células, principalmente na região mesial da polpa coronária; edema no tecido conjuntivo pulpar, evidenciado na região central da polpa; alteração vascular, com acúmulo de eritrócitos e leucócitos dentro da luz dos vasos, principalmente na raiz mesial do dente movimentado. Essas alterações foram menos evidentes no período de $72 \mathrm{~h}$. Dessa forma, conclui-se que o movimento dentário provoca alterações pulpares teciduais compatíveis com processo inflamatório, as quais são reversíveis se a agressão não ultrapassar o limite de tolerância do tecido.

\section{ACKNOWLEDGEMENTS}

The authors would like to thank the company Morelli (Sorocaba, SP, Brazil) for supply of the coil springs used in this study. This work was supported by a grant-in-aid from CAPES (Coordenação de Aperfeiçoamento de Pessoal de Nível Superior) Foundation.

\section{REFERENCES}

1. Santamaria Jr. M, Milagres D, Stuani AS, Stuani MBS, Ruellas ACO. Initial changes in pulpal microvasculature during orthodontic tooth movement: a stereological study. Eur J Orthod 2006;28:217-220.

2. Andreasen JO, Andreasen FM, Andreasen L. Textbook and color atlas of traumatic injuries to the teeth. 4th ed. Oxford: Blackwell Munksgaard; 2007.

3. Butcher EO, Taylor AC. The vascularity of the incisor pulp of the monkey and its alteration by tooth retraction. J Dent Res 1952;31:239-247.

4. Stenvick A, Mjör IA. Pulp and dentine reactions to experimental tooth intrusion. A histologic study of the initial changes. Am J Orthod 1970;57:370-385.

5. Anstendig HS, Kronman JH. A histological study of pulpal reaction to orthodontic tooth movement in dogs. Angle Orthod 1972;42:50-55.

6. Nixon CE, Saviano JA, King GJ, Keeling SD. Histomorphometric study of dental pulp during orthodontic tooth movement. J Endod 1993;19:13-16.

7. Mostafa Y, Iskander KG, El-Mangoury NH. Iatrogenic pulpal reactions to orthodontic extrusion. Am J Orthod Dentofac Orthop 1991;99:30-34.

8. Sübay RK, Kaya H, Tarim B, Sübay A, Cox CF. Response of human pulpal tissue to orthodontic extrusive applications. J Endod 2001;27:508-511.

9. Heller IJ, Nanda R. Effect of metabolic of periodontal fibers on orthodontic tooth movement. Am J Orthod 1979;75:239258.

10. Neville BW, Damm DD, Allen CM, Bouquot JE. Oral \& maxillofacial pathology. 2nd ed. Philadelphia: Saunders; 2002.

11. Rang HP, Dale MM, Ritter JM. Principles of Pharmacology. Edinburgh: Churchill Livingstone; 2003.

12. Barwick PJ, Ramsay DS. Effect of brief intrusive force on human pulpal blood flow. Am J Orthod Dentofac Orthop 1996;110:273-279.

13. McDonald F, Pitt Ford TR. Blood flow changes in permanent maxillary canines during retraction. Eur J Orthod 1994;16:1-9.

14. Ten Cate AR. Oral histology: development, structure, and function. St. Louis: CV Mosby; 1998.

15. Bhaskar SN. Orban's Oral Histology and Embryology. St. Louis: CV Mosby; 1991.

16. Hamersky PA, Weimer AD, Taintor JF. The effect of orthodontic force application on the pulpal tissue respiration rate in the human premolar. Am J Orthod 1980;77:368-378.

17. Taintor JF, Shalla C. Comparison of respiration rates in different zones of rat incisor pulp. J Dentistry 1978;6:63-70.

18. Stuani AS. Histologic aspects of periodontium on pressure side submited a orthodontic force. [Master's degree thesis]. Rio de Janeiro: School of Dentistry, Federal University of Rio de Janeiro; 2003. 175 p.

Accepted October 26, 2006 